\title{
Bureaucrats and Movie Czars: Canada's Feature Film Policy since $2000^{1}$ \\ Charles Tepperman ${ }^{2}$
}

UNIVERSITY OF CALGARY

c.tepperman [AT] ucalgary.ca

\begin{abstract}
:
This essay provides a case study of one nation's efforts to defend its culture from the influx of Hollywood films through largely bureaucratic means and focused on the increasingly outdated metric of domestic box-office performance. Throughout the early 2000s, Canadian films accounted for only around 1 percent of Canada's English-language market, and were seen by policy makers as a perpetual "problem" that needed to be fixed. Similar to challenges found in most film-producing countries, these issues were navigated very differently in Canada. This period saw the introduction of a new market-based but cultural "defense" oriented approach to Canadian film policy.
\end{abstract}

Keywords: Film Policy, Production, Canada

\section{Introduction}

For over a century, nearly every film-producing nation has faced the challenge of competing with Hollywood for a share of its domestic box office. How to respond to the overwhelming flood of expensively produced and slickly marketed films that capture most of a nation's eyeballs? One need not be a cultural elitist or anti-American to point out that the significant presence of Hollywood films (in most countries more than 80 percent) can severely restrict the range of films available and create barriers to the creation and dissemination of homegrown content. ${ }^{3}$ Diana Crane notes that even as individual nations employ cultural policies to develop their film industries, these efforts "do not provide the means for resisting American domination of the global film market." In countries like Canada, where the government plays a significant role in supporting the domestic film industry, these challenges have political and 
policy implications. How should a medium-sized film industry support its own domestic production and evaluate its success $?^{5}$ A recent special issue about this topic in The International Journal of Cultural Policy notes the lack of research on "the effectiveness of concrete policy programmes" and seeks to redress this by examining case studies of several nations. ${ }^{6}$ Some key patterns emerge from these studies, as the editors note:

[C]ontemporary film policies have tended to rely less upon ideas of the "defense" of national industries and cultures than a concern to reposition "indigenous" film activity within the global market-place and engage in pursuit of "transnational" opportunities for funding and creative collaboration. $^{7}$

But even as similar tensions between the national and transnational contexts-as well as cultural and economic motives-can be identified in most countries, they were navigated very differently by Canadian policy makers during the first decade of the twentieth century. This period saw the introduction of a new market-based but cultural "defense" oriented approach to Canadian film policy. This essay examines the motivation, implementation, and ultimately, failure of these strategies.

The 1990s was a period of rapid expansion in the Canadian film industry and also for the international reputation of English-Canadian cinema. As Atom Egoyan, Patricia Rozema, Bruce McDonald, and other directors earned both domestic and international festival success, a New Wave of Canadian indie cinema was evidently emerging. Despite the widespread critical success of these films and filmmakers, policy makers identified a problem: not enough Canadians were going to see these movies at the theater. What ensued was a wholesale revamping of Canadian feature film policy and funding designed to boost the audiences for Canadian films. The result was a new approach, the From Script to Screen policy, introduced in 2000 by Canada's minster of heritage and implemented by Telefilm Canada, the principal funding agency for dramatic feature filmmaking in Canada. The policy designated box-office success (specifically, a 5 percent share of the domestic market) as its principal goal, and the outcomes of this focus on box-office success were consequential in a number of ways: the policy boosted the production of certain kinds of films that were seen as audience friendly, it diminished auteur filmmaking by directors who had previously been critically successful, and it placed challenges in front of new directors emerging in the early 2000s.

Anxiety about "success" has plagued Canadian film policy since 1968, when the federal government first established the Canadian Film Development Corporation (later Telefilm Canada) to invest in domestic feature film production. ${ }^{8}$ Almost immediately, conflicts emerged about whether the principal objectives of government support should be (1) overall industry growth, (2) the production of popular films, or (3) the production of culturally significant films. Such debates flared up in the 1970s as David Cronenberg's early horror films (including Shivers) proved successful at the box office but were easy targets for cultural critics. By the 1990s, both scholars and policy makers were tracking the "absent audience" of Canadian film, noting that despite many years of government support, Canadian films still did not capture much more than 2 percent of the domestic box office. ${ }^{9}$ More recent accounts have challenged this dominant narrative of failure by pointing to the exponential industry growth since the 1990s (largely thanks to runaway productions stimulated by tax credits). 
But even as Canada's film industry has expanded, the question of how it supports domestic feature filmmaking-and to what ends-remains largely unresolved.

This essay examines the ways that Telefilm funding regimes influenced the kinds of Englishlanguage Canadian films that were made during the first decade of the twenty-first century. In particular, it is focused on the problems of shifting criteria and centralized decision making at this agency. This research draws on an analysis of Telefilm and Government of Canada documents as well as popular and trade press coverage to analyze the various forces at play in reshaping English-Canadian film production during this period. My focus in this work is on the actions and discourse of Telefilm Canada in relation to English-language film production. ${ }^{10}$ Both within Telefilm and outside that organization, conventional wisdom during this period held that the smaller French-language market in Canada had very different dynamics than the larger English-language one. Throughout the 2000s, French-language films were seen to be performing fairly well at the box office, claiming as much as 20 percent of the Canadian French-language box office. English-Canadian films accounted for only around 1 percent of the much larger English-language market, and were seen as a perpetual "problem" that needed to be fixed. ${ }^{11}$ And while the French-language industry continued to produce both popular successes and emerging auteur talents, English-language films were largely unsuccessful on both fronts, producing few mainstream hits and very few emerging talents. For these reasons, it makes sense to examine Telefilm's English-language Canadian film in its own right, by examining the policy shifts, discourses, and decisions that reshaped the Canadian film landscape in the early 2000s.

Some competing ways of interpreting this period of Canadian film history and the effects of the From Script to Screen policy have emerged. Some scholars claim that there are strong correlations between the industry's overall growth and the opportunities provided to Canadian filmmakers. As Peter Urquhart argues,

[A] thriving service sector is actually a pre-requisite for the existence of a healthy domestic feature film industry and not an impediment to one. This is because a large and highly skilled workforce has been created through the expansion of the service sector, and this professional workforce is available to domestic production as well ... Service production creates employment, generates capital, and contributes greatly to the production infrastructure-all in the aid of the domestic industry. ${ }^{12}$

This kind of "rising tide" argument asserts that a robust commercial industry raises the prospects of all those working in films, including auteur filmmakers, in effect resolving the persistent tension in film policy between economic and cultural objectives. However, other studies have called such a correlation into question, noting that while service production helps to establish a skilled (primarily below-the-line) workforce, it does little to support the growth of the "creative capabilities" of Canada's film industry. ${ }^{13}$

Contrasting Urquhart's position is one that traces the distinct set of institutions and supports for indie filmmaking of the kind that emerged in Ontario during the 1980s and 1990s. Brenda Longfellow notes that the Toronto New Wave filmmakers emerged from a combination of local film collectives, arts council grants, and regional and national film agency support at a time when those bodies were more open to low-budget, art-house fare. ${ }^{14}$ By the end of the 1990s, though, the Ontario Film Development Corporation no longer supported film production using grants, and Telefilm's new policy in the 2000s raised additional concerns about the 
future of Canadian auteur filmmaking. Longfellow, writing in 2005 about the new From Script to Screen regime, notes that while "prestige directors like Egoyan and McDonald" would likely continue to find funding for their work, it was less certain that "the creative and social environment that nurtured these directors at the beginning of their careers will be in place to facilitate the next cycle of maverick new wavers." ${ }^{15}$ Longfellow's concern about the disappearance of a distinct sphere of production for auteur and indie filmmakers would prove to be well founded. During the first decade of the twentieth century, we observe a turn away from measures that gauged success by a film or director's critical reception and reputation, and towards criteria that rewarded the film's marketability and domestic box-office performance. Corresponding to this shift, we find a change of emphasis in funding policy from one that privileged the creative role of director to one that rewarded the business acumen of producers. This resulted in a "producers cinema," similar to the "cinema des producteurs" that Will Higby identifies in French cinema of the 1990s, with its support for (relatively) big-budget genre and heritage films. ${ }^{16}$ But rather than a producers cinema designed for transnational success-as we see in most European industries during this period-Canadian feature film policy promoted a producers cinema geared toward success at the domestic box office.

\section{"Stursberg Picks the Winners": Producers and Box-Office Performance}

Several factors influenced the shaping of the From Script to Screen policy, most notably the rapid expansion of the Canadian film industry in the 1990s and a corresponding increased prominence of film producers. The Canadian film industry tripled in size between 1987 and 1993, resulting in the formation of the Canadian Film and Television Producers Association (CFTPA, now Canadian Media Producers Association or CMPA), an organization that soon became "the most powerful influence shaping broadcast and cultural policy."17 When the Canadian government established an advisory committee on Feature Film Policy in 1998, it was led by prominent members of the CFTPA, including producers like Robert Lantos, but did not include any directors or screenwriters. The report's focus on increased production and marketing budgets and automated funding mechanisms based on commercial success reflected this group's financial interests. ${ }^{18}$ Taking its direction from the advisory committee's report, the From Script to Screen policy was officially introduced by Heritage Canada in October 2000 and was implemented starting in early 2001 by Telefilm Canada. The policy articulated four broad objectives:

To develop and retain talented Canadian creators by investing in screenwriting and professional development for filmmakers; To foster the quality and diversity of Canadian film by restructuring (production and distribution) support programs to reward ongoing performance and by encouraging an increase in average production budgets; To build larger audiences at home and abroad through more effective support for marketing and promoting Canadian films; and To preserve and disseminate our collection of Canadian feature films for audiences today and tomorrow. ${ }^{19}$

Telefilm policy would ultimately focus primarily on the middle two of this group, and the principal focus was on building larger audiences in Canada for Canadian films. In particular, 
the government set a goal of achieving 5 percent domestic market share for Canadian films by 2005. To achieve these objectives, the agency sought to increase the average budget of Canadian films (to $\$ 5$ million) and provide marketing budgets (of $\$ 500,000$ or more) for films that showed market promise (all figures in Canadian dollars). ${ }^{20}$ Telefilm also administered the new Canadian Feature Film Fund (CFFF), which doubled overall funding for feature films from approximately $\$ 50$ to $\$ 100$ million per year. Matters of "performance" became a central preoccupation of Telefilm for the next decade: all sights were set toward achieving the 5 percent market share goal. As Telefilm noted, "The new fund [CFFF] is focused on performance. Its primary objective is to build larger audiences for Canadian features in order to see them capture a 5\% share of the domestic box office by 2006." ${ }^{21}$ However, Telefilm's 5 percent goal was greeted with skepticism by some members of the film community. Victor Loewy, chief executive officer (CEO) of Alliance Atlantis, one of Canada's largest distributors, described the goal as "a masturbatory illusion," noting that "the films produced in English Canada are not commercial enough ... The whole thing is flawed." 22

But even though the From Script to Screen policy was greeted with skepticism by many film industry insiders, it was soon reshaping the role of Telefilm and exerting a noticeable effect on the kinds of films being produced in Canada. To achieve its box-office goals, Telefilm introduced new funding mechanisms that rewarded the past box-office success of producers. Central among these was the automatically triggered funding that had been recommended by the original advisory committee: "The performance-based [funding] component of the CFFF provides envelopes for companies that do well at the box office and allows them to produce the films of their choice." 23 These "performance envelopes" were based on the principle that funding for successful producers did not require the same project-by-project oversight, because the producers already had a track record of commercial success. The goal of this mechanism was to provide more stable funding, with fewer bureaucratic obstacles, to producers who were likely to help Telefilm achieve their 5 percent goal. One consequence of this decision, however, was that performance envelopes acted as an inducement to producers and production companies who had previously avoided or not required Telefilm support to make use of it. This was certainly the case for Don Carmody, whose long track record as a producer of successful Canadian films and co-productions (including the Resident Evil franchise) triggered his eligibility for a performance envelope. Thus, Telefilm's new policy structure had a consequence of investing in companies that had not previously relied on government support. ${ }^{24}$

Besides these "performance envelopes," Telefilm also had a "selective component" of funding available to all film producers. The "selective component" was adjudicated by Telefilm officials with support for larger-budget films requiring approval from a national committee. ${ }^{25}$ Some of the most dramatic changes in Telefilm's funding criteria concerned this category, and the newly appointed director of Telefilm, Richard Stursberg, drew criticism for its abrupt implementation: in May 2002, Telefilm rejected all eight English-language films that applied for feature funding via the "national competition." ${ }^{26}$ Stursberg explained the new criteria that had been used to evaluate these films, and which became known in the industry as "The Math":

Put simply, our new policy for investment in feature films is this: we are generally not prepared to invest more than $\$ 1$ million in a film if it does not stand a reasonable chance of making more than $\$ 1$ million at the [domestic] box office. ${ }^{27}$ 
With this, Stursberg drew a direct connection between Telefilm investment and projected box-office results. As he goes on to explain, this had important ramifications for the kinds of films that could be funded:

In the past, we may have allowed ourselves to become too preoccupied with auteur filmmaking. That resulted in a period when Canadian films won a lot of prizes but not much commercial success.

Now, we need to support a range of genres with more comedies, more family movies and kids' pictures, more thrillers and romances ...

That's a change in how we do business, but our priority for Canadian feature films is simple-it's all about building audience. ${ }^{28}$

In this way, Stursberg transformed a policy focus on box-office success into a practical set of criteria for Telefilm funding. Although the focus in these statements was on box-office success, eligibility for Telefilm's CFFF also required a high degree of Canadian content, including a stipulation that it "not disguise its Canadian location." ${ }^{29}$ Such requirements appear similar to the United Kingdom's "Cultural Test" for tax relief, but unlike those requirements which were capacious enough to permit transnational Hollywood productions like The Dark Knight (2008) to qualify as British, Telefilm's guidelines stipulated that funded films should be "aimed primarily at the Canadian theatrical market."

While the blunt application of "The Math" jolted the Canadian production community, Telefilm's track record for picking winners during this period was dismal. The first English-language film to receive funding under the new "Math" regime was a Canadian/ UK co-production project called Bleeding, which was attached to Canadian film and TV director Stephen Surjik and Vancouver production company Crescent Entertainment (producers of TV shows like The Dead Zone). According to the Telefilm news release,

"The creative team behind Bleeding has an impressive track record," said Richard Stursberg, Executive Director of Telefilm Canada, "and we're delighted to be playing a major role in bringing this project to the screen. With its strong storyline, sharply drawn characters and high production values, Bleeding is exactly the kind of project that the Canada Feature Film Fund (CFFF) was designed to support. Indeed, this is an indication of the CFFF's success in supporting filmmakers who combine a deeply personal vision, a commitment to the highest cinematic standards, and a keen desire to appeal to as large an audience as possible." ${ }^{31}$

After some announcements of upcoming production in early 2003, Bleeding disappeared from the radar; it is not clear that it was ever produced or released. By November 2002, Telefilm had announced an additional eight English-language films that were funded under the new criteria. Stursberg stressed the importance of the shift in Telefilm's strategy in a news release: "Other countries have succeeded in building their domestic cinemas ... We can too, by encouraging more audience-friendly films and distributing them well." ${ }^{2}$ The news release cited strengthened requirements for distribution and advertising as key elements of telefilm funding. Of the films funded in the 2002 cycle, only Mambo Italiano (2003) would achieve any significant box-office success (approximately \$3 million in Canada and a similar amount in the United States). ${ }^{33}$ In subsequent years, the national competition yielded few English-language hits (including the bilingual Bon Cop, Bad Cop (2006), whose major box-office success came in Quebec). 
Many English-Canadian directors and producers responded to these shifts in funding priorities in negative ways. Successful auteur directors scrambled to adjust to the new reality; Telefilm's original pledge to loan "\$2-million of [Deepa Mehta's Republic of Love's (2003)] projected \$6-million cost" evaporated once the new "market initiative" was put in place. ${ }^{34}$ And both producers and directors alike protested that Telefilm was simply not a good judge of the commercial promise of different films. Stursberg's focus on box-office success was touted even as he accompanied a program of auteur films to the Museum of Modern Art in March 2004. "Can films get made that Canadians want to pay money to go to see?" Stursberg asked.

It's a huge change for English Canadian cinema, for people to be saying, "Well how about we make some things that people might like to watch?" as opposed to being completely preoccupied with making films d'auteur and getting prizes at festivals? ${ }^{35}$

Although critics noted that festival success was not incompatible with box-office success, Stursberg doggedly retained his characterization of the films screening at MoMA as "somber" and "beautiful," but "difficult" films that "are not going to make a big connection' at the box office." ${ }^{36}$ Alan King, director of one of the films in the program, disputed Stursberg's claim that his film in the MoMA program, Dying at Grace (2003), would not attract much of an audience, noting that it had done exactly that when it aired on TVOntario and "tripled the usual audience numbers for its time slot." ${ }^{37}$ King was especially critical of Stursberg's focus on the popular: "Most audiences want a fresh voice, a fresh view-not an automated film authored by a poll." 38 This example also highlights another factor, which is the important-but discountedrole that television played as a venue for Canadian films. In the mid-1990s, studies identified that television (not movie theaters) was the principal way that Canadian films were watched, noting that the Canadian Broadcasting Corporation's (CBC) broadcasts of feature films could attract several hundred thousand viewers. ${ }^{39}$ However, this number declined as the $\mathrm{CBC}$ moved the screening of Canadian films to a later time slot, and in 1999, Canada's broadcasting regulator (the Canadian Radio-Television and Telecommunications Commission [CRTC]) actually reduced the quota for Canadian dramatic works (including feature films) on television. ${ }^{40}$ Here, we see an example of another cultural policy working against Canadian film objectives, as well as Telefilm's own tunnel-vision focus on theatrical exhibition at the expense of other possible viewing platforms.

Critics of Stursberg's policy also pointed out that highly touted attempts to make more audience-friendly films often fell flat at the box office. For example, the much-hyped Foolproof (2003) had a budget of $\$ 8$ million and $\$ 3$ million spent on promotion, but it was still a box-office failure. ${ }^{41}$ However, one Famous Players Canada executive described Foolproof as a "commendable failure" because the production company worked with the exhibitor to promote the film to a popular audience. ${ }^{42}$ Stursberg's policy contributed to the ballooning budget of another film, Goose! (later released as Goose on the Loose, 2006) from \$5 million to \$11 million. ${ }^{43}$ After initial audience testing, the film's producer, Wendy HillTout, found that it needed further work, and Telefilm offered an additional \$1 million of support (on top of their existing $\$ 2$ million commitment) to help polish the film further. Ultimately, actor Tom Arnold was hired to voice a newly written part for a CGI-modified goose and a wide release with significant marketing budget was planned for late 2004 or early 2005. ${ }^{44}$ Hill-Tout's production company received further Telefilm support to develop 
a new media product (website with games) that was both an educational and promotional adjunct to the film. ${ }^{45}$ In February 2005, the film's rollout was still being forecast but its release would be delayed still further; it eventually received a small release in Spring 2006, but there is no evidence that it earned a cent in a theatrical run. ${ }^{46}$ While blaming Telefilm for the success or failure of individual films might seem unreasonable, the agency's overall weak track record did not deter Telefilm from this funding strategy. The period also saw box-office failures of Robert Lantos-produced big-budget films by Bruce McDonald and Atom Egoyan (\$12 million each). ${ }^{47}$ Despite the agency's support for more audience-friendly films, bigger budgets, producers with strong track records, and coordinated marketing efforts, success at the box office proved elusive. ${ }^{48}$

\section{The Telefilm "Studio"}

By 2005-2006, Telefilm was announcing that they had surpassed their goal of 5 percent market share for Canadian film productions. In fact, this success proved transitory and radically unevenly split across English/French-language lines: in 2005, the market share of English-language Canadian films was 1.1 percent; French-language market share was 26.6 percent. The following year, the French-language market would return to more normal levels bringing the overall Canadian average down below 5 percent again. In July 2004, Richard Stursberg had abruptly departed from Telefilm (for a post at the CBC), and it fell to his successor, Wayne Clarkson, to continue pursuing Telefilm's mandate for a larger portion of the domestic box office. ${ }^{49}$ Clarkson had served on the 1998 advisory committee that helped frame the initial terms of the From Script to Screen policy. Over the course of his term at Telefilm, Clarkson would place less of an emphasis on "The Math" but still focused on box-office performance as the primary metric of success. Although Clarkson's style was more conciliatory than Stursberg's had been, the focus on domestic theatrical audiences remained, and his five-year term as executive director was bumpy.

Less than a year after Clarkson's arrival, the government's Standing Committee on Heritage conducted an extensive review of Canadian Film policy, in which it offered a scathing assessment of Telefilm, suggesting that "for better or for worse, [Telefilm] has become part of the problem." ${ }^{50}$ In particular, the report criticized Telefilm's decision-making procedures:

In effect, Telefilm operates something like a Hollywood film studio. It decides what projects to support, invests in them and recoups equity. Unfortunately, none of the market disciplines that apply to the studio system apply to Telefilm. During the past few years Telefilm has developed mechanisms for scrutinizing larger projects. There is no evidence that these mechanisms have produced the desired results in the English-language market. ${ }^{51}$

Rather than having centralized funding decisions made by Telefilm execs, the committee recommended some kind of peer review process. "In a word," the committee reported, "officials should not be deciding what projects to support. They should decide the type of projects eligible for support, but the choice of individual projects should be made by peers and experts from outside Telefilm. ${ }^{52}$ Within Canadian government agencies and compared with literary or arts funding, this kind of bureaucratic decision-making process was unique to Telefilm. 
Rather than instituting a jury system, Clarkson sought instead to establish more expertise in project selection and appointed a film "czar" to approve English-language productions. The goal was to introduce greater transparency in the funding process, so that Telefilm support would no longer rest with a faceless and unaccountable "national decision committee." Actor and director Sarah Polley noted,

I'm so glad that national committee has been disbanded. It was five white business guys in a room, making every decision, and you never knew what happened in those rooms. I felt there were agendas that had nothing to do with the future of this industry. ${ }^{53}$

Others, like Robert Lantos, argued that the position would make little difference because the real problem was the failure of distributors to make major commitments (and take on risk) to marketing English-Canadian films. ${ }^{54}$ Clarkson's selection was the Canadian Film Centre alum and Hollywood-based executive Michael Jenkinson, who was producer of Undercover Brother and founder of the independent production company Urban Entertainment. Jenkinson would be tasked with approving all of Telefilm's English-language investments over \$1 million. A month later, however, it was announced that Jenkinson would not be able to take on the position due to Hollywood commitments, thus leaving Clarkson in the lurch. ${ }^{55}$ Clarkson himself took on the responsibility of approving English-language productions until he promoted Stephanie Azam to the position in September $2008 .^{56}$ With a background in both film and commerce, and experience at American indie distributor Zeitgeist Films, Azam's approach marked a divergence from the early From Script to Screen strategy promoted by Stursberg: "For me, commercial means we are going to find an audience for our films . . It doesn't mean we won't make auteur-driven films. One does not exclude the other." ${ }^{27}$ The key, for Azam, was in the niche marketing of Canadian films, along the same lines that she had promoted independent, documentary, and art films for Zeitgeist: "Canadian film is indie film," she noted, "It's the exact same thing."

Although the From Script to Screen policy focused on box-office performance, issues related to film exhibition received little attention during this period. Indeed, the 2005 Heritage committee noted that the "near complete absence of programs aimed at supporting film exhibition is perhaps the area where Canada differs most significantly from [Australia, France, Germany and the United Kingldom]." ${ }^{59}$ While some who were consulted for the report recommended exhibition quotas, this was not seriously examined due to the limits of federal policy. In Canada, film distribution and exhibition fall under provincial jurisdiction, so "Canadian content quotas cannot be mandated by the federal government."60 Ultimately, the report dealt with deficiencies in exhibition through a voluntary mechanism, "a challenge":

The Committee directly challenges the exhibitors of English-language Canadian films to double the amount of screen time of these Canadian films annually. Such an increase would help expose audiences to a greater number of English-language Canadian films, thus giving expression to the feature film policy in a much more meaningful way. ${ }^{61}$

The recommendation recalls the ineffectual system of "voluntary quotas" introduced by the Canadian government in the 1970s, and the national press noted the naïveté of such an approach. $^{62}$ 
Both critics and bureaucrats also noted that the From Script to Screen policy's exclusive focus on theatrical performance overlooked the fact that people viewed Canadian films in many non-theatrical contexts, including "conventional broadcasting, pay-per-view, specialty and digital services, PVRs, DVDs and videos, video-on-demand, peer-to-peer file sharing, and film festivals." ${ }^{63}$ Respondents to the Heritage Committee's investigation generally agreed that performance measures should be expanded to include non-theatrical audiences. ${ }^{64}$ Some industry figures suggested that the CBC and other broadcasters should take a greater role in funding and exhibiting Canadian films. Clarkson later promoted the idea of a stronger link between Canadian feature film production and Canadian broadcasters. A Telefilm-sponsored study released in 2009 noted that most countries with similar film industries (United Kingdom, France, Germany, etc.) placed greater requirements upon broadcasters (especially public ones like the British Broadcasting Corporation [BBC]) to fund and present their feature films. ${ }^{65}$ But these policy recommendations remained (and still remain) unfulfilled.

Telefilm's efforts to reward success and performance continued to provoke controversy over the decade. The 2005 Heritage Committee report noted that performance envelopes were not working as they were supposed to and recommended some form of "slate" rather than project funding. Robert Lantos criticized the way Telefilm administered the performance envelopes and their support for excessively commercial films such as Silent Hill (2006) and Resident Evil: Apocalypse (2004), "Hollywood movies based on video games." The Globe and Mail noted,

Don Carmody, the Toronto producer of these films, has prospered under new rules intended to build Canadian box office by rewarding previous success with a \$3.5-million envelope, no-stringsattached, but his retort to Lantos is, "Hey, at least I am shooting in Canada." Lantos's Being Julia (2004), which also got Telefilm money, was shot abroad. ${ }^{66}$

Once again, the multiple objectives of Telefilm's policy-achieve higher box office, support domestic film industry, encourage culturally significant filmmaking-seemed to be in conflict. As journalist Kate Taylor notes,

The problem is that Telefilm, perpetually undecided as to whether it is an investment banker lending money to movies with commercial potential or a cultural agency giving grants to artists, is trying to do both, and so gets criticized from all sides. ${ }^{67}$

Telefilm would routinely tinker with performance envelopes and other performance measures for the rest of the decade.

There were some English-language successes during this period. Deepa Mehta's Water (2005) was nominated for an Academy Award and Sarah Polley's Away from Her (2006) received American distribution and critical acclaim (Polley credits Clarkson with the funding for her film). ${ }^{68}$ These were not at all what Stursberg had in mind for audience-oriented Canadian films; rather, they were director-driven films that received critical acclaim and a resulting measure of box-office success. Globe and Mail critic Liam Lacey suggests that by 2006, the change in leadership at Telefilm had resulted in a toning down of the "rampant commercialism" of the first half of the decade. Unfortunately, the larger-budget genre films that appeared at the Toronto International Film Festival in 2006 suffered a similar fate to 
Foolproof when it was time for their commercial release. The \$11 million zombie comedy Fido (2006) received some festival acclaim and a theatrical release, but ultimately only grossed about US\$300,000 (\$426,000 worldwide). ${ }^{69}$ The following year proved somewhat more encouraging for the English-Canadian market, with box-office success for the bilingual Bon Cop, Bad Cop and English-language Trailer Park Boys: The Movie (2006).

The year 2007 saw English-Canadian box-office share dip below 1 percent again. By this time, press reports of the English-Canadian box-office share were no longer content with the overall improvements of Canadian figures, which were typically buoyed by FrenchCanadian success:

In 2007, Canadian English-language films earned only 1 per cent of the \$729.1-million that Englishlanguage movies grossed from Canadian theatres. Certainly this is better than the 0.3 per cent recorded in 2001-but is 1 per cent anyone's idea of a celebratory moment? ${ }^{70}$

Clarkson would break down this development a little differently in 2006, citing the growth in English-Canadian box office between 2001 and 2006 as a 600 percent growth, "from \$2 million annually to approximately \$12 million today."

Toward the end of his term at Telefilm, Clarkson was much more clear-eyed about some of the goals that the From Script to Screen policy had set out. The period between 2005 and 2010 saw the Canadian portion of box office decline, though over the decade, Telefilm was increasingly using the metric of comparing Canadian films with the rest of the independent box office (excluding major studio films). ${ }^{72}$ According to this metric, Canadian box-office share rose from 23.3 percent of the independent market in 2006 to 31.1 percent in $2007 .{ }^{73}$ In general, Clarkson expressed frustration with the 5 percent goal, referring to it in 2009 as "The 5\% box office solution that isn't." While he acknowledges that this target had been Telefilm's primary objective, it was increasingly implausible over the decade because there were no increases in funding to keep pace with rising costs. "Our 5\% box-office objective is a mirage. We don't have the resources. We barely did! We need new measureables . . . new objectives and the resources to achieve them." "The particular "measureables" that Clarkson proposed here were the non-theatrical audiences of Telefilm-funded films. "It is not about box-office-it is about Canadian audiences ... whatever the platform."

By the end of the decade, Canada's share of the domestic box office had dipped to 3.3 percent, down from its high-point of 5 percent (and without the Carmody-produced Resident Evil: Afterlife (2010), which grossed nearly \$7 million in Canada, this figure would have been lower still). ${ }^{75}$ Wayne Clarkson's term ended and Carole Brabant took over as executive director of Telefilm in 2010. The following year saw a decisive shift away from an exclusive focus on box-office success. Instead, Telefilm introduced a new "Success Index" that included recognition for awards and film festival appearances, as well as ancillary markets and DVD sales. ${ }^{76}$ Under the new system, the domestic box-office receipts made up only 40 percent of the total score and were balanced by non-theatrical and international commercial performance (20 percent), "cultural" success such as awards and festival selections (30 percent), and industrial support (10 percent). ${ }^{77}$ While Telefilm had been moving away from the domestic box-office metric for some time, the "Success Index" made it official that domestic boxoffice performance would no longer determine a filmmaker's track record. 


\section{Implications of the From Script to Screen policy}

Even after a decade of audience-oriented funding decisions, Canadians were not going to see significantly more English-language Canadian films at the theater; in this sense, the From Script to Screen policy failed in its primary objective. Nor is there any evidence that the overall growth of the Canadian film industry since the 1990s has resulted in either a more popular or critically acclaimed English-language filmmaking. No doubt, a handful of new, audienceoriented directors emerged, Michael Dowse (FUBAR, Goon) probably the most significant among them. However, producers who had achieved market success in the past without Telefilm's support also turned to Telefilm for funding, as is evidenced in the public spat between the two producer heavyweights, Robert Lantos and Don Carmody ${ }^{78}$ Furthermore, and perhaps most significantly, where was the new generation of auteur directors? One index of this drop is the Cannes Directors Fortnight, which during the 1980s and 1990s screened numerous English-Canadian films and launched the careers of auteurs such as Patricia Rozema, Atom Egoyan, and Don McKellar. The period from 2000 to 2011 saw several new French-Canadian directors at the Fortnight, but not a single English-Canadian film screened there. ${ }^{79}$ Jacob Tierney also noted that support for young filmmakers was lacking in Canada; by 2007, he could not get his second film funded, even after his first film screened in Venice and Toronto. "I found it incredibly difficult," he says, "The biggest problem now is the astounding seven-year average between your first and second film. I think it's a crippling way to treat younger artists who often have a lot to offer." ${ }^{\text {" }}$ Although Tierney's complaint came at a moment when young filmmakers in Canada were starting to feel that things were improving, they remarked on the profoundly discouraging previous several years.

In 2012, The Globe and Mail published a collection of responses from people in the Canadian film world that completed the sentence: "What Canadian film needs ..." Foremost among these responses was Patricia Rozema's fourteen-point manifesto, which touched on a range of factors, including the multiplatform world of film consumption, the need for a more inclusive and creative system, and the need for greater investment from public funds, private sector, and the United States. ${ }^{81}$ Accompanying Rozema's manifesto were shorter responses from thirteen Canadian directors, producers, and programmers. The responses range from pleas for greater risk taking and creativity (Cameron Bailey, Ruba Nadda, and Peter Raymont) to more practical fixes such as greater broadcaster investment (Lantos), marketing support (Martin Katz and Don Carmody), and theatrical exhibition quotas (Ingrid Veninger).$^{82}$ There are clearly a range of different opinions about how best to "fix" Canadian film. Perhaps it is director Mina Shum who addresses the psychology of this situation most directly:

What the Canadian film most needs right now is a good shrink. She wants to be more Hollywood with bigger budgets and movie stars, and this role play works for her sometimes, but she also yearns to be loved for being different. And when she's embraced all sides of herself, she still asksdid anybody see me today $?^{83}$

After over a decade of the From Script to Screen policy, these responses-and perhaps Shum's most of all-capture the continuing struggle that Canadian policy makers have in articulating both what their film industry needs and also what it wants. 
Telefilm's implementation of the From Script to Screen policy provides a valuable case study of one nation's efforts to defend its culture from the influx of Hollywood films through largely bureaucratic means and focused on the increasingly outdated metric of domestic box-office performance. It also highlights three significant factors that were determining for the Canadian context but are also more broadly applicable. First, policy is political, and often stems from politically appealing but economically improbable objectives (such as the cultural defense of an unprotected market). We see this in the original impetus for the From Script to Screen policy, which sought to promote a market-oriented policy while still championing national culture. Second, policy is multiple, contradictory, and susceptible to poor implementation. As we have observed, Telefilm struggled to achieve its mandate without being able to substantially address issues of film exhibition or television regulations; moreover, its track record of "picking winners" was dismal. Third, and finally, policy is unpredictable and frequently has unintended consequences. Telefilm's shift from supporting auteur cinema toward more audience-oriented filmmaking was deliberate, but its stunting effect on a generation of English-language directors and Canadian film culture more broadly was likely not. Perhaps Telefilm's more recent recognition that audiences for Canadian films are to be found in many places, including international festivals, can begin to reverse the damage done.

${ }^{1}$ This research was completed with support from the Social Sciences and Humanities Research Council (Canada) and the Calgary Institute for the Humanities. The author would like to thank Mary Arnatt, Joel Sutherland, and Katie Wackett for their research assistance on this project; thanks also to Donna Brunsdale, Lee Carruthers, Gregory Taylor, the two anonymous readers, and the MIJ editors for their valuable comments and suggestions.

${ }^{2}$ Charles Tepperman is Associate Professor in the Department of Communication, Media and Film at the University of Calgary. He has published articles on early cinema in Canada and on nontheatrical film culture and technology. He is the author of Amateur Cinema: The Rise of North American Moviemaking, 1923-1960 and is Director of the Amateur Movie Database Project (www.amateurcinema.org). His current research examines production culture and the role of the producer in contemporary Canadian screen industries.

${ }^{3}$ In describing this situation, Toby Miller and others have articulated a "Global Effects Model" through which nations interpret the popular influx of Hollywood film as both industrial and cultural threats. Toby Miller, Nitin Govil, John McMurria, Richard Maxwell, and Ting Wang, Global Hollywood 2 (London: BFI, 2005).

${ }^{4}$ Diana Crane, "Cultural Globalization and the Dominance of the American Film Industry," International Journal of Cultural Policy 20 (4, 2014): 378.

${ }^{5}$ Crane categorizes Canada as a medium-sized film producer, producing fifty-one to one hundred films per year, 370-71.

${ }^{6}$ John Hill and Nobuko Kawashima, "Introduction: Film Policy in a Globalized Cultural Economy," International Journal of Cultural Policy 22 (5, 2016): 668.

${ }^{7}$ Hill and Kawashima, "Introduction: Film Policy," 669.

${ }^{8}$ See Michael Dorland, So Close to the State/s: The Emergence of Canadian Feature Film Policy (Toronto, ON, Canada: University of Toronto Press, 1998); Ted Magder, 
Canada's Hollywood: The Canadian State and Feature Films (Toronto, ON, Canada: University of Toronto Press, 1993); Manjunath Pendakur, Canadian Dreams and American Control (Detroit, MI: Wayne State University Press, 1990).

${ }^{9}$ Complicating matters, Canada is considered part of the US domestic box office, but in this essay, "domestic box office" will generally refer only to the Canadian segment of this. Charles R. Acland, "Popular Film in Canada: Revisiting the Absent Audience," in A Passion for Identity: Canadian Studies for the 21st Century, ed. David Taras and Beverly Rasporich (Toronto, ON, Canada: ITP Nelson, 1997).

${ }^{10}$ My study brackets the lesser (if still important) role that other federal bodies (such as the National Film Board of Canada [NFB] or Canada Council of the Arts), provincial agencies (such as the Ontario Film Development Corporation [OFDC] or Société de développement des entreprises culturelles [SODEC]), and broadcasters (such as Canadian Broadcasting Corporation [CBC] and private broadcasters) play in the film production landscape.

${ }^{11}$ Figures from Marlene Catterall, "Scripts, Screens, Audiences: A New Feature Film Policy for the 21st Century," Standing Committee on Canadian Heritage (Ottawa, ON, Canada: Government of Canada, 2005), 83.

12 Peter Urquhart, "Film and Television: A Success?" In Cultural Industries.ca: Making Sense of Canadian Media in the Digital Age, ed. Ira Wagman and Peter Urquhart (Toronto, ON, Canada: Lorimer, 2012), 26.

${ }^{13}$ Michael Coutanche, Charles H. Davis, and Emilia Zboralska, "Telling Our Stories: Screenwriters and the Production of Screen-Based Culture in English-Speaking Canada," Canadian Journal of Communication 40 (2, June 2015): 58.

${ }^{14}$ Brenda Longfellow, "Surfing the Toronto New Wave," in Self Portraits: The Cinemas of Canada since Telefilm, ed. André Loiselle and Tom McSorley (Ottawa, ON: Canadian Film Institute, 2006), 184.

${ }^{15}$ Longfellow, "Surfing the Toronto New Wave," 196.

${ }^{16}$ Will Higby, "Towards a Multiplicity of Voices: French Cinema's Age of the Postmodern," in French National Cinema, ed. Susan Hayward and Will Higby, 2nd ed. (NY: Routledge, 2005), 298.

${ }^{17}$ Longfellow, "Surfing the Toronto New Wave," 182, 184-85.

18 "The Road to Success," Report of the Feature Film Advisory Committee, Department of Canadian Heritage, Government of Canada, 1999.

19 Telefilm Canada, "Annual Report, 2000-2001" (Montreal, QC: Telefilm Communications and Public Affairs, 2001), 29.

${ }^{20}$ During the same decade, the average cost of a British film was around US\$13 million and a French film was approximately US\$5.1 million. The average cost of a major Hollywood film was between $\$ 60$ million and $\$ 100$ million, with marketing budgets almost as high in addition. See Crane, 367; Peter S. Grant and Chris Wood, Blockbusters and Trade Wars: Popular Culture in a Globalized World (Toronto, ON, Canada: Douglas and McIntyre, 2004), 65.

${ }^{21}$ Telefilm Canada, "Annual Report, 2001-02" (Montreal, QC: Telefilm Communications and Public Affairs, 2002), 27.

${ }^{22}$ Denis Seguin, "The 5\% Solution," Canadian Business, 75 (17, September 16, 2002).

23 "Annual Report, 2001-02," 10. 
${ }^{24}$ It is worth noting, though, that Carmody used his Telefilm funding for relatively low-budget films that he might not have otherwise produced.

${ }^{25}$ While Telefilm's regional offices made funding decisions for low-budget productions, films with a potential Telefilm investment over $\$ 1$ million were evaluated by the "national committee."

${ }^{26}$ Seguin, "The 5\% Solution."

${ }^{27}$ Richard Stursberg, "The ABC of Audience Building in Canada-Film: Can We Do It?" (keynote address presented to Academy of Canadian Cinema \& Television Speaker Series, Vancouver, BC, Canada, November 13, 2002), (via Wayback Machine) http:// web.archive.org/web/20131018012044/http://www.telefilm.ca/upload/flash/ Stursberg-Film-speech.pdf.

${ }^{28}$ Ibid.

${ }^{29}$ In addition, the guidelines stipulated that qualifying films achieve at least a score of 8 out of 10 on the Canadian Audio-Visual Certification Office point scale. Telefilm Canada, "The Canadian Feature Film Fund-Interim Guidelines: Development, Production and Marketing Programs, 2001-2002" (Montreal, QC: Telefilm Canada, March 29, 2001), 10.

${ }^{30}$ John Hill, "Living with Hollywood: British Film Policy and the Definition of "Nationality,"' International Journal of Cultural Policy 22 (5, 2016): 717.

${ }^{31}$ Telefilm Canada Office of Communications and Public Affairs, "Telefilm Canada Backs the Dramatic Feature Film Bleeding from Director Stephen Surjik" [Press Release], July 10, 2002 (via Wayback Machine) http://web.archive.org/ web/20131017190911/http://www.telefilm.ca/en/news/releases/2002/07/10/ telefilm-canada-backs-dramatic-feature-film-bleeding-director-stephen-surji

32 Telefilm Canada Office of Communications and Public Affairs, "Telefilm Canada Builds Box Office Success with Audience-Friendly Film Projects" [Press Release], November 13, 2002, (via Wayback Machine) http://web.archive.org/web/20131017190823/ http://www.telefilm.ca/en/news/releases/2002/11/13/telefilm-canada-buildsbox-office-success-audience-friendly-film-projects.

${ }^{33}$ The other films funded include Falling Angels, Republic of Love, A Problem with Fear, An Intern's Diary, Les Belles Soeurs, Great Goose Caper, and Eating the Bones. See also Ian Edwards, "Stursberg Picks the Winners," Playback, November 25, 2002, http://playbackonline.ca/2002/11/25/winners-20021125/.

${ }^{34}$ Telefilm ultimately provided half of the funding it had originally pledged to this production, and this reduction had direct repercussions: it was no longer possible to shoot on location in Winnipeg (where Carol Shields's novel was set), so Mehta re-imagined the storyline with a Toronto setting. Ray Conlogue, "Another Story Entirely," The Globe and Mail, January 7, 2003, p. R1.

${ }^{35}$ Simon Houpt, "New York Turns Spotlight North," The Globe and Mail, March 6, 2004, p. R14.

${ }^{36}$ Houpt, "New York Turns Spotlight North," p. R14.

${ }^{37}$ Alan King, "Canadian Box Office," The Globe and Mail, March 10, 2004, A20.

${ }^{38}$ King, "Canadian Box Office," A20. Around the same time, Sarah Polley made a similar critique of the Telefilm policy at the 2004 Genie Awards: "I don't think the answer to making our films more accessible is to make dumber, more commercial movies"; 
Liam Lacey, "Barbarian Invasions Is Gem of Genies," The Globe and Mail, May 2, 2004.

${ }^{39}$ Ted Magder, "Film and Video Production," in The Cultural Industries in Canada, ed. Michael Dorland (Toronto, ON, Canada: Lorimer, 1994), 151.

${ }^{40}$ Grand and Wood, Blockbusters and Trade Wars, 232. See also Amanda Coles, "Counting Canucks: Cultural Labour and Canadian Cultural Policy" (PhD diss., McMaster University, 2012), especially chapter 4.

${ }^{41}$ Figures from Longfellow, "Surfing the Toronto New Wave," 194.

${ }^{42}$ Gayle MacDonald and James Adams, "Ready for Their Close-Up," The Globe and Mail, May 1, 2004, R9.

${ }^{43}$ MacDonald and Adams, "Ready for Their Close-Up," R1, R8.

${ }^{44}$ MacDonald and Adams, "Ready for Their Close-Up," R1, R8.

${ }^{45}$ Telefilm Canada, "New Media 2006 Catalog," (via Wayback Machine) http://web .archive.org/web/20131017040441/https://www.telefilm.ca/en/catalogues / production/randall-s-goosefun-goose-loose; see also "Rare Method Goes Hollywood," The Globe and Mail, January 4, 2006.

${ }^{46}$ James Adams, "Telefilm Fires Its Hollywood Agents," The Globe and Mail, February 12, 2005, p. R3. The version that later aired on CBC television in 2011 showed signs of further revisions, with Dave Foley (not Tom Arnold) as the voice of the goose.

${ }^{47}$ Longfellow, "Surfing the Toronto New Wave," 194.

${ }^{48}$ Telefilm tracked some of the shift that was taking place from more auteur-oriented to audience-friendly filmmaking in their own record-keeping. Their 2004-2005 annual report noted, "Since the launch of the Canadian Feature Film Fund, Telefilm has invested in 98 films produced in English, of which 50 percent were 'auteur' films." Most of the films in this category likely fell into the "low-budget independent feature" category geared toward first-time filmmakers and regional diversity. Shifts in this metric are impossible to track, though, because subsequent Telefilm reports do not provide statistics about auteur support; Telefilm Canada, "Annual Report, 2004-2005" (Montreal, QC: Telefilm Communications and Public Affairs, 2005), 50.

${ }^{49}$ Clarkson had a long track record in supporting distinctive Canadian filmmaking, including roles as head of the Toronto Film Festival, "first CEO of the Ontario Film Development Corporation (where he launched the Toronto new wave) and ... the head of the Canadian Film Centre (which he turned into a hothouse for low-budget filmmaking)." Wyndham Wise, "From the Editor," Take One, December 2004, p. 5.

${ }^{50}$ Catterall, "Scripts, Screens, Audiences," 128-29.

${ }^{51}$ Catterall, "Scripts, Screens, Audiences," 129.

${ }^{52}$ Ibid., 143.

${ }^{53}$ Gayle MacDonald, "Film Industry: Mystery Czar Meets His Clients," The Globe and Mail, April 25, 2006, p. R1.

${ }^{54}$ Gayle MacDonald, "Telefilm to Appoint Film Czar," The Globe and Mail, April 20, 2006, p. R1.

${ }^{55}$ Gayle MacDonald, "Filmmakers Shrug Off Defection," The Globe and Mail, May 18, 2006, R1.

${ }^{56}$ Telefilm Canada Office of Communications and Public Affairs, "Telefilm Canada Announces Appointment of National Feature Film Executive English-Language 
Market" [Press Release], September 4, 2008, (via Wayback Machine) http:// web.archive.org/web/20131017190045/https://www.telefilm.ca/en/news / releases /2008/09/04/telefilm-canada-announces-appointment-nationalfeature-film-executive-engli.

${ }^{57}$ Gayle MacDonald, "The Script Stops Here," The Globe and Mail, January 7, 2009, p. R1.

${ }^{58}$ Marc Glassman, "Stephanie Azam's Amazing Adventure," Playback, May 11, 2009. http://playbackonline.ca/2009/05/11/azam-20090511/.

${ }^{59}$ Catterall, "Scripts, Screens, Audiences," 96.

${ }^{60}$ Catterall, "Scripts, Screens, Audiences," 36.

${ }^{61}$ Catterall, "Scripts, Screens, Audiences," 139.

${ }^{62}$ Kate Taylor, "How Telefilm Can Make Movies, Not Just Deals," The Globe and Mail, December 10, 2005, p. R2.

${ }^{63}$ Catterall, "Scripts, Screens, Audiences," 56.

${ }^{64}$ Catterall, "Scripts, Screens, Audiences," 56.

${ }^{65}$ Peter S. Grant and Michel Houle, "Expanding the Audience with Television Platforms," Telefilm Canada, February 2009, pp. 65-66, http://www.telefilm.ca/ en/telefilm/corporate-publications /other-studies.

${ }^{66}$ Kate Taylor, "No End in Sight to Telefilm's Conundrum," The Globe and Mail, April 29, 2006, p. R4.

${ }^{67}$ Taylor, "No End in Sight to Telefilm's Conundrum," p. R4.

${ }^{68}$ Gayle MacDonald, "Film Industry: Mystery Czar Meets His Clients," The Globe and Mail, April 25, 2006, p. R1.

${ }^{69}$ Liam Lacey, "Our Filmmakers Hit Their Stride," The Globe and Mail, September 16, 2006, p. R18. Box-office figures from BoxOfficeMojo.com.

70 James Adams, "Film: 28th Annual Genie Awards: A Very Good Year, a Very Bad Year," The Globe and Mail, March 3, 2008, p. R1.

${ }^{71}$ Wayne Clarkson, "Artistic Directions: The Challenge of English Canadian Cinema Past, Present and Future" (speech delivered to the Directors Guild of Canada, November 25, 2006), 7.

72 This idea of comparing the performance of Canadian films to foreign independent films, rather than Hollywood films, was raised in the 2005 Heritage Committee report; Catterall, "Scripts, Screens, Audiences, 59.

73 Telefilm Canada, "Annual Report, 2007-2008" (Montreal, QC: Telefilm Communications and Public Affairs, 2008), 6.

${ }^{74}$ Wayne Clarkson, "Change and Opportunity for the Creative Age" (speech delivered to CFTPA Prime Time in Ottawa, ON, Canada, February 20, 2009), 9.

75 Telefilm Canada, "Annual Report,2010-2011"(Montreal,QC:Telefilm Communications and Public Affairs, 2011).

${ }^{76}$ Liam Lacey, "Culture Beats Box Office: Telefilm Gets It Right," The Globe and Mail, November 25, 2011, p. R1.

77 Telefilm Canada, "Success Index," https://telefilm.ca/en/business-intelligence/ success-index. Accessed July 28, 2017.

${ }^{78}$ Kate Taylor, "No End in Sight to Telefilm's Conundrum," The Globe and Mail, April 29, 2006, p. R4. 
${ }^{79}$ It is also notable that several French-Canadian auteurs have had significant international acclaim, and some-Denis Villeneuve and Jean-Marc Vallée in particularhave left Canada to pursue successful careers in Hollywood.

${ }^{80}$ Gayle MacDonald, "Lights, Camera and, Finally, Some Action," The Globe and Mail, February 10, 2007, p. R1.

${ }^{81}$ Patricia Rozema, "A Manifesto for Our Movies," The Globe and Mail, March 8, 2012, p. R3.

82 Rozema, "A Manifesto for Our Movies," p. R3.

${ }^{83}$ Rozema, "A Manifesto for Our Movies," p. R3.

\section{Bibliography}

Acland, Charles R. "Popular Film in Canada: Revisiting the Absent Audience." In A Passion for Identity, edited by David Taras and Beverly Rasporich. Toronto, ON, Ontario: ITP Nelson, 1997.

Coles, Amanda. "Counting Canucks: Cultural Labour and Canadian Cultural Policy." PhD diss., McMaster University, 2012.

Coutanche, Michael, Charles H. Davis, and Emilia Zboralska. "TellingOur Stories: Screenwriters and the Production of Screen-Based Culture in English-Speaking Canada." Canadian Journal of Communication 40, no. 2 (June 2015).

Crane, Diana. "Cultural Globalization and the Dominance of the American Film Industry: Cultural Policies, National Film Industries, and Transnational Film." International Journal of Cultural Policy 20, no. 4 (2014): 365-82.

Dorland, Michael. So Close to the State/s: The Emergence of Canadian Feature Film Policy. Toronto, ON, Canada: University of Toronto Press, 1998.

John Hill, "Living with Hollywood: British Film Policy and the Definition of "Nationality," International Journal of Cultural Policy 22, no. 5 (2016): 706-23.

Hill, John and Nobuko Kawashima. "Introduction: Film Policy in a Globalised Cultural Economy," International Journal of Cultural Policy 22, no. 5 (2016): 667-72.

Grant, Peter S. and Chris Wood, Blockbusters and Trade Wars: Popular Culture in a Globalized World. Toronto, ON, Canada: Douglas and McIntyre, 2004.

Hayward, Susan and Will Higby. French National Cinema. 2nd ed. New York: Routledge, 2005.

Longfellow, Brenda. "Surfing the Toronto New Wave." In Self Portraits: The Cinemas of Canada since Telefilm, edited by André Loiselle and Tom McSorley. Ottawa, ON: Canadian Film Institute, 2006.

Magder, Ted. Canada's Hollywood: The Canadian State and Feature Films. Toronto, ON, Canada: University of Toronto Press.

Magder, Ted. "Film and Video Production." In The Cultural Industries in Canada, edited by Michael Dorland. Toronto, ON, Canada: Lorimer, 1994. 
Media Industries 4.2 (2017)

Miller, Toby, Nitin Govil, John McMurria, Richard Maxwell, and Ting Wang. Global Hollywood 2. London: BFI, 2005.

Pendakur, Manjunath. Canadian Dreams and American Control. Detroit, MI: Wayne State University Press, 1990.

Urquhart, Peter. "Film and Television: A Success?" In Cultural Industries.ca, edited by Ira Wagman and Peter Urquhart. Toronto, ON, Canada: Lorimer, 2012. 